\title{
PENGARUH KEMANDIRIAN BELAJAR MATEMATIK SISWA TERHADAP KEMAMPUAN BERPIKIR KREATIF MATEMATIS SISWA SMP
}

\author{
Fuji Sri Astuti ${ }^{1}$, Tri Buana Bintang ${ }^{2}$, Rizka Vita Utami ${ }^{3}$, Padillah Akbar ${ }^{4}$ \\ 1,2,3,4 IKIP Siliwangi, Jl. Terusan Jenderal Sudirman, Cimahi Tengah, Kota Cimahi, Jawa Barat, 40526 \\ Fsri265@gmail.com
}

\begin{abstract}
This research aims to analyze and in study about influence of mathematical by self regulated learning against the ability of mathematical creative thinking high school students. The methods used in this research is quantitative data with the correlational method. The population in this research is a high school student in the city of Karawang with sampels as many as 32 student that assigned by techniques purposif sampling at one high school in the city of Karawang. The instruments in this research is a test of the ability of mathematical creative thinking as much as 4 items and scale self regulated learning as much as 10 scale statements.
\end{abstract}

Keywords: Mathematical Creative Thinking, Self Regulated

Abstrak

Penelitian ini bertujuan untuk menganalisis dan menelaah tentang pengaruh kemandirian belajar matematik siswa terhadap kemampuan berpikir kreatif matematis siswa SMP. Metode yang digunakan dalam penelitian ini adalah metode korelasional dengan data kuantitatif. Populasi dalam penelitian ini adalah siswa SMP di Kota Karawang dengan sampelnya sebanyak 32 orang yang ditetapkan dengan teknik purposif sampling pada salah satu SMP Negeri di Kota Karawang. Instrumen dalam penelitian ini berupa tes kemampuan berpikir kreatif matematis sebanyak 4 butir soal dan skala kemadirian belajar matematik siswa sebanyak 10 skala pernyataan.

Kata kunci: Berpikir Kreatif Matematis, Kemandirian Belajar Matematis.

Matematika adalah ilmu yang sudah mendunia bagi keberlangsungan kehidupan manusia (Nurhayati, 2019; Isnaeni, 2019; Rahmawati, 2019) dalam perkembangan di bidang teknologi infomasi dan komunikasi saat ini (Wiliawanto, 2019). Perkembangan dibidang tersebut sangat pesat karena adanya peranan matematika di bidang teori-teori matematika dalam pemecahan masalah (Akbar, 2018). Untuk menguasai dan menciptakan teknologi maka diperlukan penguasaan dan pemahaman atas matematika yang kuat sejak dini (As'ari, Tohir, Valentino, Imron, \& Taufiq, 2017; Bernard, 2014; Rohaeti, 2019). Mata pelajaan Matematika yang wajib diberikan kepada semua siswa untuk acuan mereka dalam menggali informasi dengan kemampuan berpikir logis, analitis, sistematis, kritis, inovatif dan kreatif. Selain itu, siswa dalam pembelajaran diberikan stimulus untuk dapat memahami konsep matematika (Bernard, 2018) dengan menyelesaikan berbagai masalah-masalah dalam konteks materi matematika, seperti mencari ide-ide dalam menyelesaikan permasalahan, mengembangkan konsep,mencari permasalahan serta mengemukakan hasil permasalahan dengan ideide yang mereka dapatkan melalui proses dan tugas matematika (Hidayat, 2019) dan mampu mengembangkan di dalam matematika sendiri (Timutius, 2018; Chotimah, 2018).

Menurut Supardi, (2015) menghadapi situasi pendidikan, proses belajar mengajar merupakan salah satu dari bentuk kegiatan kreatif seperti melalui proses belajar mengajar. Lalu kreativitas siswa dapat muncul tiba-tiba tanpa dengan adanya paksaan atapun paksaan dan sembarang tempat, oleh karena itu perlu dilatih agar kemunculannya dalam menemukan ide tidak waktu yang tepat dan bahkan pada sembarang tempat, tetapi ide kreativitas ini harus ada tepat waktu saat menghadapi berbagai permasalahan matematika. Kemudian berpikir kreatif dapat memberikan siswa agar lebih 
termotivasi dalam pembelajaran, terutama bagi siswa yang masih kurang tingkat berpikir kreatif akan berusahan dan yang tingkat kreatif tinggi akan berperan sebagai motivasi.

Menurut Dilla, Hidayat, \& Rohaeti (2018) kemampuan berpikir kreatif adalah kemampuan yang mempunyai komponen kognitif untuk peserta didik dalam menunjang suatu keberhasilan pembelajaran mereka. Tetapi pembelajaran yang menggunakan suatu kemampuan kreativitas saat ini jarang sekali diperhatikan saat pembelajaran matematika berlangsung. Padahal kemampuan berpikir kreatif dalam pembelajaran matematika sangat penting untuk dapat meningkatkan daya kreatif siswa terhadap permasalahan yang dihadapi, karena dengan memiliki kemampuan tersebut ia akan lebih mudah menghadapi masalah dan menyelesaikannya dengan kemampuan yang ia miliki. Dengan kata lain, siswa dapat dilatih menyelesaikan masalah, mencari masalah, mencari ide untuk menyimpulkan masalah (Siswanto, 2018), lalu siswa itu akan berusaha mengambil keputusan, dan terakhir siswa akan berdiskusi dengan temannya (saling bertukar informasi). Sebab siswa itu telah menjadi terampil tentang bagaimana mengumpulkan informasi yang relevan, menganalisis informasi yang diperoleh, dan akan berpikir untuk meneliti kembali hasil atau memeriksa kembali yang telah diperolehnya dengan ide yang mereka temukan.

Menurut Ismaimuza (2013) keberhasilan dari upaya berpikir kreatif ditinjau dari secara keseluruhan contohnya seperti pencapaian sekolah, pembelajaran menggunakan berbasis masalah. Masalah yang diambil untuk siswa yaitu mendapat permasalahan yang bersifat kontekstual artinya masalah dapat dicari sesuai fakta keadaan, atau situasi yang berpotensi dalam hal permasalahan kognitif pada pelajar. Hal ini menunjukkan bahwa berpikir kreatif mempunyai kriteria-kriteria yang mengarah kepada mencari informasi berdasarkan ide yang dimiliki. ada beberapa ciri-ciri komponen berpiki kreatif yang mempunyai 4 komponen yaitu (Hendriana \& Soemarmo, 2014).

\section{Tabel 1}

Komponen Berpikir Kreatif

\begin{tabular}{|l|l|}
\hline \multicolumn{1}{|c|}{ Ciri-Ciri Komponen Berpikir Kreatif } & \multicolumn{1}{c|}{ Meliputi } \\
\hline Fluency (berpikir lancar) & Mencetuskan Banyak ide; Memberi banyak cara; \\
\hline Flexibility(berpikir luwes) & Menghasilkan gagasan; \\
\hline Originality(berpikir orisinil) & $\begin{array}{l}\text { Mampu melahikan ungkapan baru; Membuat } \\
\text { kombinasi; }\end{array}$ \\
\hline Elaboration (Keterampilan Mengelaborasi) & $\begin{array}{l}\text { Mengembangkan konsep dan menambah suatu } \\
\text { gagasan. }\end{array}$ \\
\hline
\end{tabular}

Selain komponen kognitif yang dapat mempengaruhi kegiatan pembelajaran, komponen afektif juga sebagai komponen yang dapat mempengaruhi sikap siswa dalam pembelajaran matematika. Hal tersebut sama seperti yang dikemukakan oleh (Taher \& Pertama, 2013) tentang keberhasilan pembelajaran kognitif dan psikomotor dipengaruhi oleh kondisi afektif. Siswa yang dalam kondisi afekifnya positif terhadap pembelajaran akan meluapkan perasaannyadengan mempelajari mata 
pelajaran tertentu, sehingga dapat mencapai hasil pembelajaran yang optimal, walaupun masih kurang yang menggunakannya saat kegiatan pembelajaran berlangsung.

Perilaku afektif siswa dalam mewujudkan suatu keinginannya secara nyata,lalu tidak meniru atau bergantung pada orang lain maka siswa tersebut akan mampu melakukan belajar dengan cara usaha sendiri, dapat menemukan cara belajar yang efektif dengan melakukan kegiatan belajar secara mandiri. Kemampuan siswa dalam hal kemandirian belajar berdampak terhadap hasil belajar yang ia peroleh. Mandiri bukan hanya siswa belajar hanya sendirian tanpa adanya bantuan dari seorang guru, melainkan siswa dilatih untuk membuat inisiatif belajar dengan mencari ide-ide yang ia cari dari berbagai sumber dan merumuskan ide-ide (Rachmayani, 2014).

Karakteristik kemandirian belajar siswa yang dikembangkan dalam pembelajaran kognitif diantaranya yaitu: (1) memilih tujuan benar; (2) menyelesaikan kesulitan; (3) pemanfaatan fasilitas; (4) sikap kooperatif: (5) membangun makna; (6) kontrol diri (BsY, 2010). Kemudian dapat ditentukan pula berdasarkan seberapa besar inisiatif dalam mencari ide- ide dan tanggung jawab siswa untuk berperan aktif dalam hal proses perencanaan belajar maupun evaluasi belajar. Semakin besar peranan siswa dalam berbagai kegiatan aktif tersebut, maka siswa tersebut telah memiliki tingkat kemandirian belajar yang tinggi (Fahradina, I, Ansari, \& Saiman, 2014).

Berdasarkan berbagai permasalahan diatas, maka perlu dilakukan hasil belajar yang merupakan puncak dari aktivitas belajar siswa yang dapat menghasilkan perubahan dalam pengetahuan (kognitif), sikap (afektif), dan tingkah laku (psikomotor) yang dapat diamati (Suhendri, 2012). Maka perlu dilakukan penelitian yang menjadi permasalahan tentang seberapa besar kemampuan berpikir kreatif matematis yang dipengaruhi oleh kemandirian belajar siswa.

\section{METODE}

Metode dalam penelitian ini menggunakan metode korelasional dengan data kuantitatif yang bertujuan untuk mengetahui dengan menganalisis secara mendalam tentang pengaruh kemandirian belajar matematik siswa SMP terhadap kemampuan berpikir kreatif matematis. Dalam penelitian ini, populasi yang digunakan siswa SMP di Kota Karawang. Sedangkan sampelnya sebanyak 32 orang yang ditetapkan secara purposif sampling pada salah satu Sekolah Menengah Negeri di Kota Karawang. Instrumen dalam penelitian ini menggunakan tes dan non tes. Instrument tes tersebut didasarkan pada penilaian karakteristik yang baik terhadap kemampuan berpikir kreatif matematis, sedangkan instrument non tes didasarkan pada penilaian karakteristik yang baik terhadap kemandirian belajar siswa. Tes kemampuan berpikir kreatif matematis sebanyak 4 butir soal dan skala kemandirian belajar matematik siswa sebanyak 10 skala pernyataan. Data hasil penelitian diolah dan dianalisis menggunakan uji statistika regresi. Namun sebelum dilakukan uji statistika regresi, dilakukan terlebih dahulu pengujian normalitas data dan uji linearitas.

Berikut adalah contoh data instrumen soal tes dan non tes yang di sajikan sebagai berikut: 
5. Diketahui kubus $A B C D . E F G H$ dengan panjang rusuk $8 \mathrm{~cm}$.

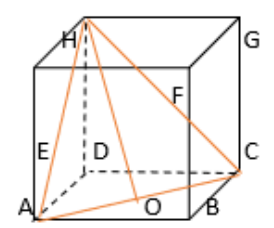

Tentukan jarak antara titik $\mathrm{H}$ ke garis diagonal sisi AC dengan minimal 2 cara yang kamu ketahui !

Gambar 1. Contoh Instrumen Tes tentang Kemampuan Berpikir Kreatif

Petunjuk 1. Beri tanda silang (X) pada SS jika anda sangat setuju, S jika anda setuju, N jika anda tidak bisa memutuskan (termasuk tidak tahu), TS jika anda tidak setuju, atau STS jika anda sangat tidak setuju di bawah masing- masing pernyataan yang bersesuaian dengan pembelajaran matematika yang baru saja kita laksanakan.

2. Waktu untuk mengerjakan angket skala sikap ini adalah 45 menit.

\begin{tabular}{|c|c|c|c|c|c|}
\hline No. & Pertanyaan & SS & $\mathrm{S}$ & TS & STS \\
\hline 1. & $\begin{array}{l}\text { Dalam pembelajaran ini saya senang } \\
\text { mengajukan pertanyaan }\end{array}$ & & & & \\
\hline 2. & $\begin{array}{l}\text { Dalam pembelajaran ini saya senang } \\
\text { membaca buku yang relevan dengan } \\
\text { bahan ajar selain buku yang sudah } \\
\text { diwajiblan. }\end{array}$ & & & & \\
\hline 3. & $\begin{array}{l}\text { Saya bersemangat untuk hadir dalam } \\
\text { pembelajaran ini. }\end{array}$ & & & & \\
\hline 4. & $\begin{array}{l}\text { Dalam pembelajaran ini saya mudah } \\
\text { melihat kekurang sempurnaan suatu } \\
\text { penvelesaian soal }\end{array}$ & & & & \\
\hline 5. & $\begin{array}{l}\text { Dalam pembelajaran ini saya suka } \\
\text { menyelesaikan tugas individual tanpa } \\
\text { bantuan orang lain }\end{array}$ & & & & \\
\hline 6. & $\begin{array}{l}\text { Dalam pembelajaran ini saya } \\
\text { bersemangat menyelesaikan tugas } \\
\text { dengan baik dan tepat waktu }\end{array}$ & & & & \\
\hline 7. & $\begin{array}{l}\text { Dalam pembelajaran ini saya berani } \\
\text { mengemukakan masalah yang tidak } \\
\text { dikemukakan orang lain }\end{array}$ & & & & \\
\hline 8. & $\begin{array}{l}\text { Dalam pembelajaran ini saya optimis } \\
\text { akan kebenaran jawaban soal yang saya } \\
\text { buat walaupun berbeda dengan teman- } \\
\text { teman }\end{array}$ & & & & \\
\hline 9. & $\begin{array}{l}\text { Dalam pembelajaran ini saya suka } \\
\text { mempertimbangkan masukan dan } \\
\text { kritikan dari teman maupun guru untuk } \\
\text { peyempurnaan penyelesaian tugas }\end{array}$ & & & & \\
\hline 10. & $\begin{array}{l}\text { Saya selalu menetapkan target ketika } \\
\text { belajar }\end{array}$ & & & & \\
\hline
\end{tabular}

Gambar 2: Contoh Instrumen Non Tes tentang Kemandirian Belajar Matematik

\section{HASIL}

Berdasarkan hasil data yang diperoleh dari dua variabel yaitu kogntif dan afektif, kemampuan berpikir kreatif dan kemandirian belajar berdistribusi normal, dan selanjutnya dilakukan uji linearitas terhadap kemampuan berpikir kreatif dengan kemandirian belajar disajikan dalam bentuk tabel 1 sebagai berikut: 


\section{Tabel 2}

Uji Linearitas Kemandirian Belajar dan Kemampuan Berpikir Kreatif

\begin{tabular}{|c|c|c|c|c|c|c|c|}
\hline & & & Sum of Squares & Df & Mean Square & $\mathbf{F}$ & Sig. \\
\hline \multirow{4}{*}{$\begin{array}{l}\text { Kemampuan Berpikir } \\
\text { Kreatif * Kemandirian } \\
\text { Belajar }\end{array}$} & \multirow{4}{*}{$\begin{array}{l}\text { Between } \\
\text { Groups }\end{array}$} & (Combined) & 78.254 & 15 & 5.217 & 9.621 & .000 \\
\hline & & \multirow{3}{*}{$\begin{array}{l}\text { Linearity } \\
\text { Deviation from } \\
\text { Linearity } \\
\text { Within Groups } \\
\text { Total }\end{array}$} & 75.555 & 1 & 75.555 .193 & 139.342 & .000 \\
\hline & & & 2.699 & 14 & & .356 & .970 \\
\hline & & & $\begin{array}{c}8.133 \\
86.387\end{array}$ & $\begin{array}{l}15 \\
30\end{array}$ & .542 & & \\
\hline
\end{tabular}

Berdasarkan hasil uji linearitas antara kemandirian belajar siswa dan kemampuan berpikir kreatif siswa SMP terdapat hubungan yang Linear. Hal ini disebabkan nilai Sig. dari Deviation from Linearity menghasilkan 0,970, (sig $>\alpha=5 \%$ ). Kemudian tingkat linearitas antara kemandirian belajar siswa dan kemampuan berpikir kreatif matematis temasuk kuat karena $(\operatorname{sig}=0.00)$. Setelah dilakukan uji linearitas maka dilakukan uji statistika regresi linear untuk memperlihatkan adanya pengaruh kemandirian belajar siswa terhadap kemampuan berpikir kreatif matematis dengan hasil pengujian menggunakan SPSS 24 dengan disajikan pada tabel 2 dan tabel 3 sebagai berikut:

\section{Tabel 3}

Uji Regresi Kemandirian Belajar Siswa dan Kemampuan Berpikir Kreatif siswa

\begin{tabular}{|cl|r|r|r|r|r|}
\hline Model & & Sum of Squares & Df & Mean Square & \multicolumn{1}{c|}{ F } & \multicolumn{1}{c|}{ Sig. } \\
\hline 1 & Regression & 75.555 & 1 & 75.555 & 202.269 & $.000^{\mathrm{b}}$ \\
& Residual & 10.833 & 29 & .374 & & \\
& Total & 86.387 & 30 & & & \\
\hline
\end{tabular}

a. Dependent Variable: Kemampuan Berpikir Kreatif

b. Predictors: (Constant), Kemandirian Belajar

\section{Tabel 4}

Model Summary

\begin{tabular}{|c|c|c|c|c|}
\hline Model & $\mathbf{R}$ & R Square & Adjusted R Square & $\begin{array}{c}\text { Std. Error of the } \\
\text { Estimate }\end{array}$ \\
\hline 1 & $.935^{\mathrm{a}}$ & .875 & .870 & .611 \\
\hline
\end{tabular}

a. Predictors: (Constant), Kemandirian Belajar

Berdasarkan pengujian regresi pada tabel 2 dan tabel 3 didapat sig. Sebesar 0,000 yang mengakibatkan bahwa adanya pengaruh positif kemandirian belajar siswa dengan kemampuan berpikir kreatif siswa pada taraf signifikasi 5\% . Lalu besarnya nilai korelasi atau hubugan $\mathrm{R}$ yaitu sebesar 0,935 dan nilai koefisien determinasi $\mathrm{R}$ Square sebesar 0.875 . Koefisien determinasi $\mathrm{R}$ 
Square menunjukkan pengaruh dari Predictors (kemandirian belajar). Hal ini dapat diartikan bahwa adanya pengaruh kemandirian belajar siswa terhadap kemampuan berpikir kreatif matematis siswa sebesar 87,5\% sedangkan 12,5\% dipengaruhi oleh faktor luar kemandirian belajar.

\section{Tabel 5}

Persamaan Regresi

\begin{tabular}{|l|l|r|r|r|r|r|}
\hline \multirow{2}{*}{ Model } & \multicolumn{2}{|c|}{$\begin{array}{c}\text { Unstandardized } \\
\text { Coefficients }\end{array}$} & $\begin{array}{c}\text { Standardized Coefficients } \\
\text { Beta }\end{array}$ & & \\
\cline { 2 - 4 } & \multicolumn{1}{|c|}{ B } & Std. Error & & \multicolumn{1}{c|}{ t } & \multicolumn{1}{c|}{ Sig. } \\
\hline \multirow{2}{*}{1} & (Constant) & 4.698 & .643 & & 7.305 & .000 \\
\cline { 2 - 8 } & Kemandirian Belajar & .278 & .020 & .935 & 14.222 & .000 \\
\hline
\end{tabular}

Adapun persamaan regresi dari hasil pengujian tentang pengaruh kemandirian siswa terhadap kemampuan berpikir kreatif matematik siswa adalah sebagai berikut:

$Y=4,698+0,278 x$

Maka konstanta sebesar 4,698 merupakan nilai konsisten dari kemampuan berpikir kreatif matematis sedangkan koefisien regresi $\mathrm{X}$ sebesar 0,278 menyatakan bahwa setiap ada penambahan kemandirian belajar maka nilai kemampuan Berpikir kreatif matematis siswa bertambah sebanyak 0,278. Sehingga dapat diinterpretasikan bahwa pengaruh kemandirian belajar terhadap kemampuan berpikir kreatif matematis siswa positif dan semakin tinggi kemandirian belajar matematik yang dimiliki siswa, maka akan semakin tinggi kemampuan berpikir kreatif matematis siswa tersebut.

Hasil analisis data dari hasil penelitian menunjukkan bahwa terdapat pengaruh yang positif antara kemandirian belajar siswa terhadap kemampuan berpikir kreatif matematis siswa, yaitu dengan melihat hasil pekerjaan siswa.Berikut hasil pekerjaan siswa dengan sikap kemandirian belajar matematik

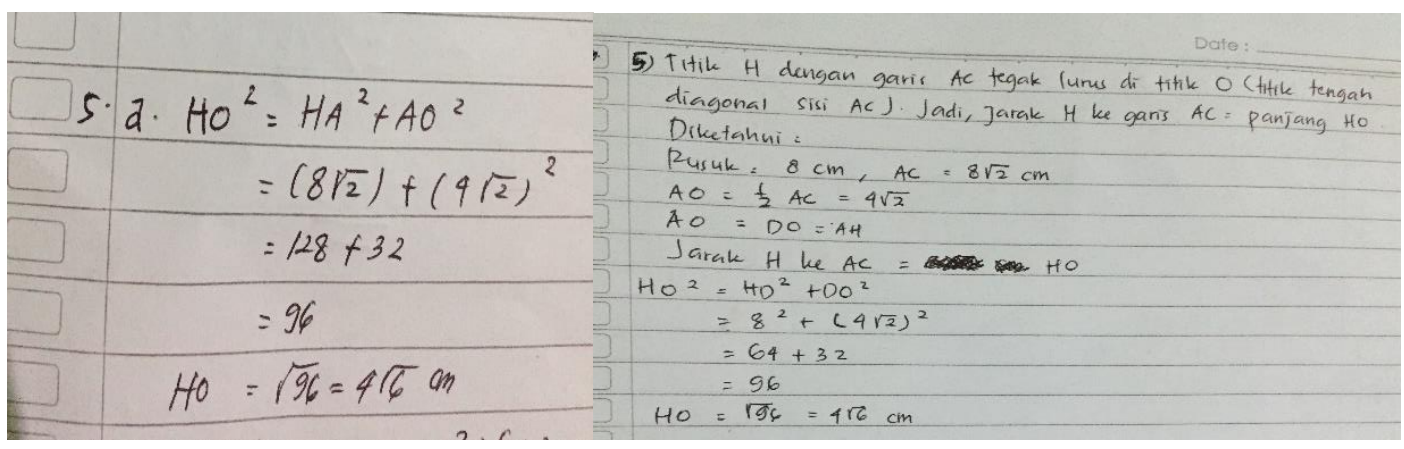

Jawaban Siswa A

Jawaban Siswa B

Gambar 3. Jawaban Siswa Kemampuan Berpikir Kreatif dan Kemandirian Belajar yang tinggi

Pada siswa A dan B terlihat siswa tersebut mempunyai ide-ide serta cara-cara menyelesaikan permasalahan matematik dengan sesuai informasi dan ide yang ia dapatkan kemudian ia kembangkan dengan konsep materi fungsi . Dari kedua jawaban tersebut, siswa A dan siswa B mempunyai pendapat yang berbeda ketika menjawab permasalahan. Ini merupakan salah satu indikator 
kemampuan berpikir kreatif dimana siswa diarahkan untuk mencetuskan banyak ide terhadap penyelesaian masalah yang kemudian dikembangkan sehingga tercipta ide-ide yang telah di terima dan siswa memiliki kemandirian yang mantap dan cenderung melakukan komunikasi dengan baik sehingga mampu memberikan gambaran nilai yang bermakna (BsY, 2010). Maka terlihat kemandirian belajar siswa A dan B dapat menghadapi persoalan-persoalan yang semakin kompleks dan mengurangi ketergantungan siswa dengan orang lain dalam kehidupan sehari-hari (Fauzi Amin, 2011).

\section{KESIMPULAN}

Berdasarkan hasil dan pembahasan, maka dapat disimpulkan bahwa kemampuan berpikir kreatif matematis siswa SMP dipengaruhi positif oleh kemandirian belajar matematik sebesar 87,5\%, sedangkan 12,5\% dipengaruhi oleh faktor selain kemandirian belajar matematik siswa. Kemudian semakin tinggi kemandirian yang dimiliki siswa, maka akan semakin tinggi kemampuan berpikir kreatif matematis siswa tersebut maupun sebaliknya.

\section{DAFTAR PUSTAKA}

Ahmad Susanto. (2013). Teori belajar mengajar dan pembelajaran di sekolah dasar.Jakarta: Kencana Prenada Media Group.

Akbar, P., Hamid, A., Bernard, M., \& Sugandi, A. I. (2018). Analisis kemampuan pemecahan masalah dan disposisi matematik siswa kelas xi sma putra juang dalam materi peluang. Jurnal Cendekia: Jurnal Pendidikan Matematika, 2(1), 144-153.

As'ari, A. R., Tohir, M., Valentino, E., Imron, Z., \& Taufiq, I. (2017). Buku Guru Matematika (Revisi). Jakarta: Pusat Kurikulum dan Perbukuan, Balitbang, Kemendikbud.

Bernard, M. (2014). Meningkatkan Kemampuan Penalaran Matematik Siswa SMA Melalui Game Adobe Flash CS 4. In InInProsiding Seminar Nasional Pendidikan Matematika (Vol. 3, pp. 205213).

Bernard, M., \& Chotimah, S. (2018, September). Improve student mathematical reasoning ability with open-ended approach using VBA for powerpoint. In AIP Conference Proceedings (Vol. 2014, No. 1, p. 020013). AIP Publishing.

Bungsu, T. K., Vilardi, M., Akbar, P., \& Bernard, M. (2019). Pengaruh Kemandirian Belajar Terhadap Hasil Belajar Matematika Di Smkn 1 Cihampelas. Journal on Education, 1(2), 382389.

Chotimah, S., Bernard, M., \& Wulandari, S. M. (2018, January). Contextual approach using VBA learning media to improve students' mathematical displacement and disposition ability. In Journal of Physics: Conference Series (Vol. 948, No. 1, p. 012025). IOP Publishing.

BsY, B. (2010). Pengembangan Kemandirian Belajar Berbasis Nilai untuk Meningkatkan Komunikasi Matematik. Jurnal Pendidikan Matematika, 1(1), 11-23. 
Dilla, S. C., Hidayat, W., \& Rohaeti, E. E. (2018). Faktor Gender dan Resiliensi dalam Pencapaian Kemampuan Berpikir Kreatif Matematis Siswa SMA. Journal of Medives, 2(1), 129-136.

Diniyah, A. N., Akbar, G. A. M., Akbar, P., Nurjaman, A., \& Bernard, M. (2018). Analisis Kemampuan Kemampuan Penalaran dan Self Confidence Siswa SMA dalam Materi Peluang. Journal on Education, 1(1), 14-21.

Fahradina, N., I, B., Ansari, \& Saiman. (2014). Peningkatan Kemampuan Komunikasi Matematis dan Kemandirian Belajar Siswa SMP dengan Menggunakan Model Investigasi Kelompok. Jurnal Didaktik Matematika, 1(1), 54-64. Retrieved from http://jurnal.unsyiah.ac.id/index.php/DM/article/download/2077/2031.

Hidayat, F., Akbar, P., \& Bernard, M. (2019). Analisis Kemampuan Berfikir Kritis Matematik Serta Kemandiriaan Belajar Siswa Smp Terhadap Materi Spldv. Journal on Education, 1(2), 515-523.

Ismaimuza, D. (2013). Kemampuan berpikir kritis dan kreatif matematis siswa smp melalui pembelajaran berbasis masalah dengan strategi konflik kognitif. Jurnal Teknologi (Sciences and Engineering), 63(2), 33-37. https://doi.org/10.11113/jt.v63.2002.

Isnaeni, S., Ansori, A., Akbar, P., \& Bernard, M. (2019). ANALISIS KEMAMPUAN KONEKSI MATEMATIS SISWA SMP PADA MATERI PERSAMAAN DAN PERTIDAKSAMAAN LINEAR SATU VARIABEL. Journal on Education, 1(2), 309-316.

Nurhayati, N., \& Bernard, M. (2019). Analisis Kesulitan Siswa Dalam Pemecahan Masalah Matematik Siswa Kelas X SMK Bina Insan Bangsa Pada Materi Persamaan Dan Pertidaksamaan. Journal on Education, 1(2), 497-502.

Rachmayani, D. W. I. (2014). Penerapan Pembelajaran Reciprocal Teaching Untuk Meningkatkan Kemampuan Komunikasi Matematis Dan Kemandirian Belajar Matematika Siswa. Jurnal Pendidikan Unsika, 2(November), 13-23.

Rahmawati, N. S., Bernard, M., \& Akbar, P. (2019). Analisis Kemampuan Komunikasi Matematik Siswa Smk Pada Materi Sistem Persamaan Linier Dua Variabel (SPLDV). Journal on Education, $1(2), 344-352$.

Rohaeti, E. E., Nurjaman, A., Sari, I. P., Bernard, M., \& Hidayat, W. (2019, February). Developing didactic design in triangle and rectangular toward students mathematical creative thinking through Visual Basic for PowerPoint. In Journal of Physics: Conference Series (Vol. 1157, No. 4, p. 042068). IOP Publishing.

Siswanto, R. D., Dadan, D., Akbar, P., \& Bernard, M. (2018). Penerapan Model Pembelajaran Kooperatif Tipe Auditorial, Intelectually, Repetition (Air) Untuk Meningkatkan Pemecahan Masalah Siswa Smk Kelas XI. Journal on Education, 1(1), 66-74.

Suhendri, H. (2012). Pengaruh Metode Pembelajaran Problem Solving Terhadap Hasil Belajar Matematika. Jurnal Formatif, 3(2), 105-114.

Timutius, F., Apriliani, N. R., \& Bernard, M. (2018). Analisis Kesalahan Siswa Kelas IX-G di SMP Negeri 3 Cimahi dalam Menyelesaikan Soal Pemecahan Masalah Matematik pada Materi 
PENGARUH KEMANDIRIAN BELAJAR MATEMATIK SISWA TERHADAP KEMAMPUAN BERPIKIR KREATIF MATEMATIS SISWA SMP, Fuji Sri Astuti, Tri Buana Bintang, Rizka Vita Utami, Padillah Akbar

Lingkaran. JPMI (Jurnal Pembelajaran Matematika Inovatif), 1(3), 305-312.

Wiliawanto, W., Bernard, M., Akbar, P., \& Sugandi, A. I. (2019). Penerapan Strategi Pembelajaran Aktif Question Student Have Untuk Meningkatkan Kemampuan Berpikir Kritis Matematik Siswa SMK. Jurnal Cendekia: Jurnal Pendidikan Matematika, 3(1), 139-148. 